\title{
The Challenges of Controlling and IT Support in Non-financial Reporting
}

\author{
Nidžara Osmanagić Bedenik \\ Tenured University Professor, Faculty of Economics and Business, University of Zagreb, Kennedyjev trg 6, 10000 Zagreb, \\ Croatia, nosmanagic@efzg.hr \\ Darko Prebežac \\ Tenured University Professor, Faculty of Economics and Business, University of Zagreb, Kennedyjev trg 6, 10000 Zagreb, \\ Croatia, dprebezac@efzg.hr \\ Ivan Strugar \\ Tenured University Professor, Faculty of Economics and Business, University of Zagreb, Kennedyjev trg 6, 10000 Zagreb, \\ Croatia, istrugar@efzg.hr

\section{Petra Barišić} \\ Postdoctoral Researcher, Faculty of Economics and Business, University of Zagreb, Kennedyjev trg 6, \\ 10000 Zagreb, Croatia, pbarisic@efzg.hr
}

Received (03.12.2018.); Revised (08.01.2019.); Accepted (13.02.2019.)

\begin{abstract}
It is nowadays becoming increasingly clear that financial reporting can no longer be sufficient when it comes to business reporting. In that sense, the non-financial reporting is a 'must' in the modern economy for different groups of the general public as it reflects the responsibility of a company to conduct business activities in a sustainable way. The non-financial reporting represents relatively new area of research, and very little research has investigated the role of controlling and IT support in nonfinancial reporting. Therefore, the aim of this study was to find the best business practices and reveale the role of controlling and IT support in the process of preparing and publishing nonfinancial reports in hotel companies in Croatia. We applied the case study approach on the hotel company llirija d.d. The results show that the role of controlling in llirija d.d. is most significant in the economic field, and it is of great importance both in the ecological and social spheres; while the IT has a significant role in preparing and tracking data for non-financial reporting.
\end{abstract}

Key words: Controlling, Hotel industry, IT support, Non-financial reporting

\section{INTRODUCTION}

In December 2014 the European Parliament adopted the Directive 2014/95/EU about nonfinancial reporting. Starting on 1 January 2017 companies of public interest with 500 or more employees will have to include a nonfinancial statement in the management report [8].

The hotel industry represents the most important segment of tourism in terms of its financial impact and in terms of its broad and comprehensive impact on the entire society. "The significance of the hotel industry has been especially pronounced in the period of economic contraction when sustainability and positive financial results prove to be the precondition for future growth, sector development and the growth of the national economy alike." [38].

In this paper we discover the best business practice in the area of sustainability reporting of biggest enterprises in hotel industry in Croatia. In this study we applied the case study approach.

The primary goal of this paper is to discover the best practice and disclose the role of controlling and IT support in preparing and publishing nonfinancial reports. Based on research of llirija d.d. nonfinancial report we strive to provide support and stimulate other hotel enterprises to publish sustainability business reports.

\section{THE SYSTEM OF NONFINANCIAL REPORTING}

Business reporting provides information on the business activity of a company, which is necessary to decisionmakers outside or inside the company. The system of business reporting includes financial and non-financial reports which are interrelated and aligned with the objective to provide a comprehensive overview of the business activities and results of a company. 
It is nowadays becoming increasingly clear that financial statements can no longer be sufficient when it comes to business reporting because they do not reflect the entire business activity of a company. The information in financial statements reflects only short-term monetary aspects of business but does not provide insight into environmental, social and managerial aspects of business which are, in the long-term, much more important. Non-financial reporting is a 'must' in the modern economy for different groups of the general public as it reflects the responsibility of a company to conduct business activities in a sustainable way. On the basis of a sample of 200 senior executive managers across the world, and according to the results of a study conducted by The Economist $87 \%$ of respondents agree that sustainability will become more important over the next few years. $57 \%$ of respondents say that their firms use sustainability reporting as a basis for new business strategies [40]. The results show that $49 \%$ of respondents report progress in meeting their environmental sustainability goals and $53 \%$ report progress towards social sustainability. There is growing evidence that sustainability reporting increases in significance. According to the results of KPMG from 2008 , almost $80 \%$ of the world's largest 250 enterprises report on sustainability [40].

Even though it seems to us that sustainability is a modern concept and problem, the first requirements for sustainable business activity date back several centuries. Hans Carl von Carlowitz (1645-1714) is considered to be the founder of the sustainability principle. In his work Sylvicultura oeconomica from 1713 he demanded, due to the crisis in raw materials (wood), that one should only lumber so many trees as can be grown by reforestation and planting. This was the demand of 'sustainable' usage and sustainable forest management soon caught as a professional term. This principle from forestry gave rise to the motto 'to live off the interest, not the capital' [5].

Contemporary terms of sustainability and sustainable development were coined in the early 1970s. The foundation of the definition of sustainability is the Brundtland report, according to which sustainable development is that development which "...meets the needs of the present without compromising the ability of future generations to meet their own needs". In other words, the goal is better quality of life for everyone now and for the generations to come. That is why modern business conditions demand a change in the dominant paradigm - from a reductionist focus on profit toward a holistic perspective and balance between economic, social and ecological aspects and dimensions of business accountability of a company [29].

Business sustainability is often defined as the triple bottom line management, a process in which companies manage their financial, social and ecological risks, threats and opportunities. These three impacts are often called "Profit, People and the Planet" or 3P - a syntagm introduced by Elkington in 1994 [10]. The concept of Corporate Social Responsibility - CSR, is being increasingly replaced by another concept, Holistic Corporate Responsibility - HCR [5]. Sustainability report is a report which provides information on economic, environmental, social and managerial aspects of a company's performance [29]. Integrated report integrates information on sustainability together with traditional financial information in a single report. It offers a comprehensive picture of value creation through time [20]. The question of motive is a question of purpose and true meaning of sustainability reporting. One may rightfully ask the following question: Why would companies invest an additional effort and report on social and ecological aspects of their business activity? Corporate social responsibility undoubtedly helps some companies to find new opportunities of value creation to ensure permanent business. These companies set goals publicly and take into account serious global problems such as climate change to distinguish themselves from less responsible companies [21]. Other similar companies were simply set up by visionary entrepreneurs with social responsibility as their foundation [2].

Sustainability reporting has significant internal and external benefits [14]. According to the results of a survey conducted by The Economist [39] among 1,254 executive managers in the world in 2007, the biggest benefits from adopting sustainable practises were reported in the following areas: ability to attract new customer base/retain existing one (37\%), improved shareholder value (34\%) and increased profitability (31\%).

Instruments of sustainability reporting include principles, guidelines, standards and methods. Major organisations adopted the following guidelines: GRI sustainability reporting guidelines, United Nations Global Compact (UNGC)- UN guidelines for business and human rights, OECD guidelines, ISO 26000 guidelines of the International Organisation for Standardisation and the Tripartite Declaration of the International Labour Organisation. Organizations have the freedom to choose the standards of reporting. They can develop their own standards of non -financial reporting as well.

Some important open questions in this area certainly include the type of data and information which are disclosed, the way the data are collected and processed and the way they are presented - in a qualitative and/or quantitative form. IT support plays a very important role in that process because collecting data for non-financial reporting is often done manually, which certainly makes the preparation of the documents harder and slower. The next open question deals with research studies in this area. An increasing number of companies which decide to disclose non-financial reports allow research to be conducted in that area as well. Since there are different standards and guidelines for such reporting and companies are free to choose reporting standards, it is often difficult to collect and process data, especially to compare different reports. It should also be stressed that the findings obtained represent a stimulus and encouragement to other companies in the process of disclosing non-financial reports.

\section{SUSTAINABILITY OR GREEN CONTROLLING}

Empirical research studies in controlling provide arguments [37] that controlling comes from the business 
practice where it is widely accepted. Controlling is recognized as active and neutral business expert, who support management in process od decision making [28]. Despite many different definitions of controlling, there are a number of similarities among various definitions that enable us to make groups of definitions and speak about different controlling generations and conceptions depending on different market situations as the main controlling determinant $[3 ; 7 ; 16 ; 17 ; 22 ; 32]$. Since there is no single generally accepted definition of controlling, there is, similarly, no single definition of controlling goals $[4 ; 17 ; 44]$. Controller's tasks were first set up in 1962 by the Financial Executive Institute, focusing on planning, controlling, reporting, interpreting, evaluating, consulting, etc. Empirical research studies followed in the next decades proving those tasks as the core of controlling. From that point of view, the main controlling goal is to support management in the process of planning, controlling, reporting, interpreting, evaluating and consulting. Controlling goals could be seen as management support to better and faster adapt to the changing situation [17; 27]. Following Eschenbach and Siller [7] controlling supports managers to maintain and develop their ability to anticipate, ability to adapt, ability to coordinate and plan realisation, which are all controlling goals. Horvath [16] stresses coordination in the management system, in particular planning, control and information system, as the main controlling functions. According to Weber and Schäffer [44] controller's tasks could be derived from the characteristics of managers and controllers. Based on that approach, the meaning and goal of controlling is to assure the rationality of management.

The present controlling orientation introduces the perspective of future goals, namely operative, strategic and normative points of view with corresponding tasks $[6 ; 7 ; 16 ; 17]$. Operative controlling deals with the efficiency of present potentials of success in the company. Strategic controlling widens the perspective in the future and focuses on the present building of future potentials of success. Effectiveness as the new and wider focus reflects the relationship between the company and its environment: what the company takes from the environment and what it gives to the environment $[1 ; 4 ; 25 ; 5]$. Normative controlling supports normative management, meaning vision, mission, values, culture and other norms regarding stake-holders, corporate governance, corporate social responsibility, compliance, and integrity of company [35].

At the end, normative controlling encompasses and integrates operative and strategic perspectives into the company's values and principles that last and make each company unique, thus distinguishing it from other companies.

The 'average' understanding of controlling in Croatian companies is viewed as assurance of management rationality [28]. In terms of generation, controllers are navigators while operative tasks dominate with internally oriented focus. What are still needed is more strategic and normative orientation, more external orientation and more freedom for controllers to create tasks and activities. [27; 28]. Management has a key role in controlling practice: since management is controller's 'custom', s/he decides about controlling conception, scope and performance. Controller tasks are determined by manager's characteristics, namely manager's motivation and abilities [44]. Therefore, management is the main stimulus - or limitation - to controlling. Empirical research in Croatian companies [27] shows that the main impulse for controlling implementation comes from management $(64 \%$ in 2001 and 54\% in 2007). In addition to that key role, IT support is also very important and could be a stimulus or a burden. At the end, or, at the very beginning, it should be stressed that successful companies have implemented successful controlling, and vice versa. Controlling and business success go together hand in hand [29; 43].

Since human activities have transformed the biosphere, leading to global climate change, biodiversity loss and various types of pollution, 'green' or sustainability controlling has been developed to support management in the face of new challenges. Not only profit, but social and environmental business aspects are becoming important, so that managers have to search for a balance between them $[29 ; 42 ; 33 ; 36 ; 42]$. Sustainability reporting is a new controlling task. Nonfinancial reporting is still done on a voluntary basis, but from 2017 it is an obligation for EU companies with more than 500 employees or for companies of special public interest, which includes approximately 6,000 large companies and groups across the EU.

Controlling is management support expert. It provides information needed for process of decision making and makes transparent consequences of different decisions. For long time business was focused on profit and short term. Because of changes in circumstances we need to shift our focus to social and environmental consequences as well. There is the role of 'green' and sustainable controlling.

Because, green is not only a color, it is a way of doing and the path to sustainability.

Green controling has an active role that goes beyond aspects of economy and economic indicators, and is increasingly focused on sensitizing, consulting and motivating management and other decision makers by constantly reviewing the environmental consequences of individual activities and business decisions. This also means the expansion of controller tasks in the direction of green goals and information.

Green business requires green information and indicators to measure, evaluate and control towards the green objectives. For controlling it means the need to integrate green subjects and content into existing economic activities. Determining green control tasks would include securing and demonstrating green economy, tracking and monitoring the achievement of green goals, promoting transparency on green issues through planning, control and reporting indicators, and integrating green content and green information into company management.

The green challenge for companies and controlling is a contribution to long-term and sustainable business success. In this context, there is an increasing role of controling in the process of non-financial reporting. 


\section{ROLE AND PERSPECTIVE OF ICT SUPPORT}

Information technology systems in the enterprise define the two essential determinants of the development of information and communication technologies (ICT) and the needs of management. The KPGM survey confirms that reporting on sustainable development has become a standard part of the business reporting plan [19]. The 2014 PwC survey shows that $61 \%$ of US investors are not satisfied with the company's published information on sustainable development [23].

Bases for standard management reporting are applications that have ensured the scope of business transactions and have enabled standardized managerial reporting. The layout and content of the standard managerial reports were pre-determined, and the works were distributed in accordance with a predetermined schedule (daily, weekly, monthly, quarterly etc). The development of databases and user interfaces enables more dynamic reporting by enabling users to input report parameters by adapting their content and form to individual user needs and serves as the base for integrated reporting system of the company.

In medium and large companies, spreadsheets as the basic tool for compiling reports are complemented with reporting programs and a new generation of integrated reporting and business intelligence tools [12]. As these software solutions are quite expensive, spreadsheets are commonly used as the basic tool for preparing managerial reports, and reports on sustainable development.

The total number of monitored indicators and indicators of sustainable development is increasing, so the Global Reporting Initiative covers over 100 indicators [15] Internet and company Web portals become very convenient and common channel for communications with stakeholders. Sometimes companies develop dynamic interfaces, a special segment of company web pages that enables users to explore annual reports thru dialog forms and boxes and reach to segments of their specific interest. In December 2015, the UN General Assembly highlighted the crosscutting contribution of information and communications technology to the Sustainable Development Goals (SDG) noting that ICTs can accelerate progress across all 17 Sustainable Development Goals [41]. Internet of things (IoT) is network of physical objects that contain embedded technology to communicate and sense or interact with their internal states or the external environment [13].

Basic infrastructure and software for loT are needed for aggregation and analysis; the data collected by sensors, help them to gain insight and expand intelligence through its consolidation and analysis, and enables the creation of promised values and extended behaviors. In these situations, there are benefits to decentralizing computing power, to placing it closer to the point where data is generated, in other words, to pursuing edge computing. Rapid deployment of loT projects for a variety of business, consumer and government use cases is driving this development. "As the volume and velocity of

data increases, so too does the inefficiency of streaming all this information to a cloud or data center for processing." [34] In the US, three main factors have driven growth in CR reporting: the most significant has been investor and shareholder interest in sustainability. Secondly, companies are also required to carry out climate change-related disclosure in Securities and Exchange Commission (SEC) filings. Lastly, the influential Sustainability Accounting Standards Board (SASB) publishes industry-specific Sustainability Accounting Standards that advise what CR disclosures organizations should include in their mandatory financial SEC filings. Taken together, these factors have driven higher reporting rates and, in particular, have significantly increased rates of companies including $\mathrm{CR}$ information in their annual reports [18].

In Croatia there are number of different organizations that record and trace data related to SDG Goals. Tourism and hospitality industry is very concerned about environmental issues and it is obvious from their interest in corporate responsibility reporting since these companies pays a lot of attention to this segment of reporting.

\section{DATA COLLECTION AND SAMPLING}

This research is focused on discovering the best business practices of nonfinancial reporting and revealing the role of controlling and IT support in the process of preparing and publishing nonfinancial reports in hotel companies in Croatia. We have conducted the qualitative research through online survey, and in the processing of the results we applied methods of descriptive statistics. When choosing the best business practice we used the case study method. The results of the study are shown in textual and graphical way.

The sample is based on the list of 30 largest companies according to the value of total revenue in 2015 in the group Hotels and Restaurants, according to FINA data published in the journal Lider (Lider media, 2016: 88-90). The research revealed that in 2016 only three hotel companies in the group of the 30 largest hotel companies publish nonfinancial report as follows: llirija d.d., Biograd na moru, Jadranski luksuzni hoteli d.d., Dubrovnik, and Valamar Riviera d.d., Poreč. These three hotel companies represent examples of best business practices in the area of reporting on sustainable development, and they make our initial research sample. Among the selected companies, to our survey responded only Illiria d.d., Biograd na moru. We conducted a survey in the period September-December 2017.

A survey of controlling was conducted through 8 closed questions about core activities in which controlling provides profesional support: defining goals, planning, control, and reporting. The IT support was investigated with 6 closed questions. The use of Likert scale enabled the ranking of individual responses.

\section{RESULTS FOR ILIRIJA D.D., BIOGRAD NA MORU}

llirija d.d., Biograd na moru is a hotel enterprise established in 1957. It is one of the leading tourism enterprises in the Zadar County and among 15 leading tourism companies in Croatia. Its business operations include the hotel industry, nautic tourism and camping. Tourism facilities of this enterprises are located in the most 
attractive and prestigious locations boasting a Blue Flag and a beautiful view to the Pašman Channel. Its near surroundings include four national parks and three nature parks which makes Biograd an ideal destination to encounter all natural and cultural beauties of Croatia. This company has won several awards in the area of sustainability and responsible tourism. This company has also received international environmental certificates of special relevance for tourism. In addition to important activities in the area of environmental protection, the company also invests a lot of efforts to promote corporate social responsibility.

On its 164 pages, the report clearly states information on corporate social responsibility and sustainability in tourism in general, and in Ilirija d.o.o. in particular [45]. The topics analysed include economic sustainability, corporate social responsibility in market relations, involvement of corporate social responsibility in the business strategy of the company, responsibility toward employees, policies and practices of environment management, CSR projects toward the community and awards of the community. Sustainable business is the foundation of the sustainable development and growth of the value of Ilirija d.o.o. "The CSR principles, sustainable development and sustainable investment represent a foundation for current and future creation and development of new markets and increase in the value of the company as well as universal values of thebusiness and social surrounding on the global level", as the resport states at its end.

\subsection{The role of controlling in non-financial reporting}

Research results show the priority role of owners, managers and financies in the process of defining goals, which is understandable, since owners define the desired framework for achievement, management assumes responsibility for achieving goals, while finances define the financial framework and financial capabilities needed to achieve the goals. The roles of sales and accounting at this stage of the management process have a smaller role (Figure 1a).

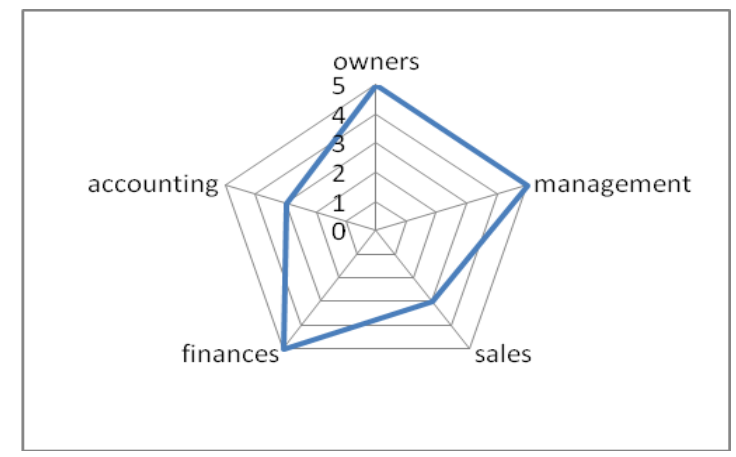

Figure 1. Role of individual stakeholders / functions in the management system

a) Defining goals

Planning process defines and mades concrete steps and activities to chieve goals. Dominant roles are still in the area of owner, management and finances. At this stage of the management process, the role of sales increases significantly and the role of accounting increases as well (Figure 1b).

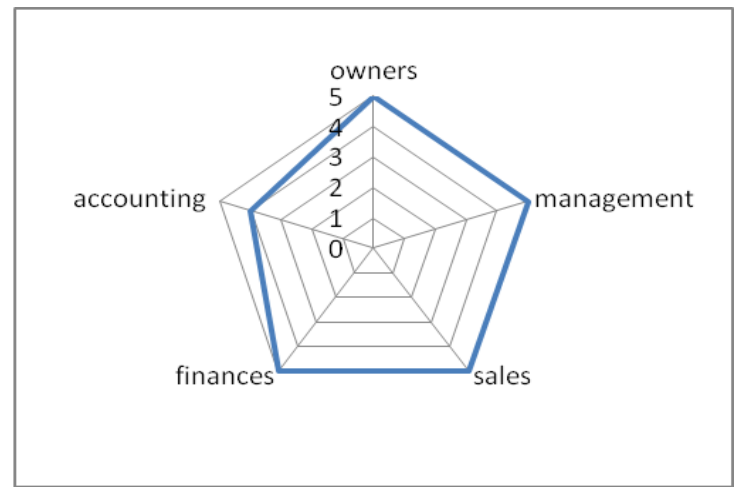

b) Planning

In the control process there is a change of roles: the owners keep track and monitor the achievement of goals and plans, while management, sales, finances and accounting play a decisive role (Figure 1c).

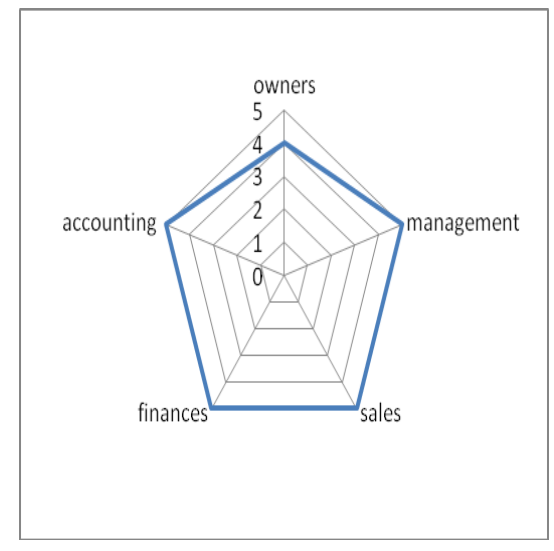

c) Control

In the reporting process there is a further change in the importance of individual roles: management, finances and accounting play the most important role, the role of sales decreases, while the role of management decreases considerably. This relationship reflects the reality, because the reporting system cooperates management and technical support, sales explains the changes in this business segment, while the owners represent the recipients of the report and are not involved in their creation (Figure 1d).

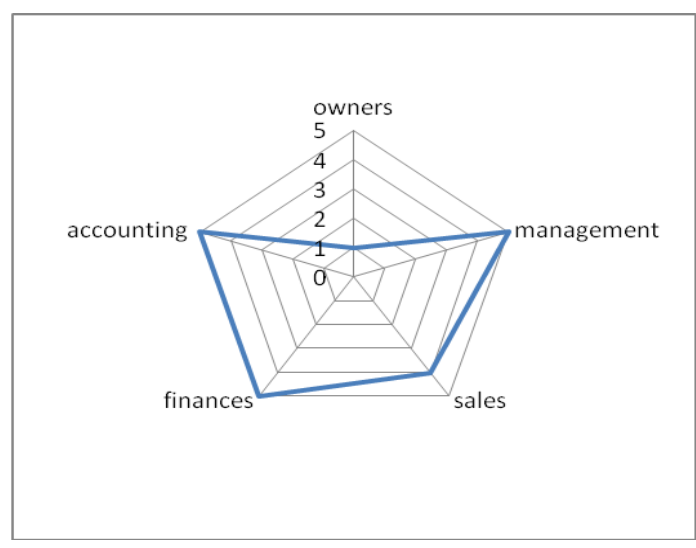

d) Reporting 
The research results show the ranking of individual stakeholders / functions in the management system. Thus:

- the goals are defined primarily by the cooperation of owners, management and finance,

- $\quad$ planning is carried out in co-operation with all of the above mentioned functions,

- control is also carried out in co-operation of all of the above functions, and

- reporting is primarily carried out in the cooperation of management, finance, and accounting departments.

The conclusion is that there is a different intensity of participation of certain stakeholders/functions in the management system, which is suited to their fundamental role in the business.

The stakeholders/function perspectives are also interesting. From this point of view we conclude that:

- owners have a major role in the process of defining goals and planning,

- management has a key role in every partial process since it assumes responsibility for the overall management and business of the company,

- finances also participate intensively in each individual process, taking into account the financial aspects of business operations,

- sales are most involved in the planning, control and reporting process, while

- accounting takes the biggest part in concrete control and reporting processes.

Controlling is, according to the most common interpretation, expert support for management in the areas of defining goals, planning, control and reporting. In the following research, we wanted to discover the role of controlling in management from the economic, social and environmental aspect.

The research results show that the role of controlling in the economic area is indispensable, in the ecological area also intensively present, while the role of controlling in the social area is somewhat weaker in intensity (Figure 2).

Such an expansion from the monetary, onedimensional and short-term perspective on the social and ecological component of business, the multidimensional and long-term perspective is challenging for all business functions, as well as for controlling.

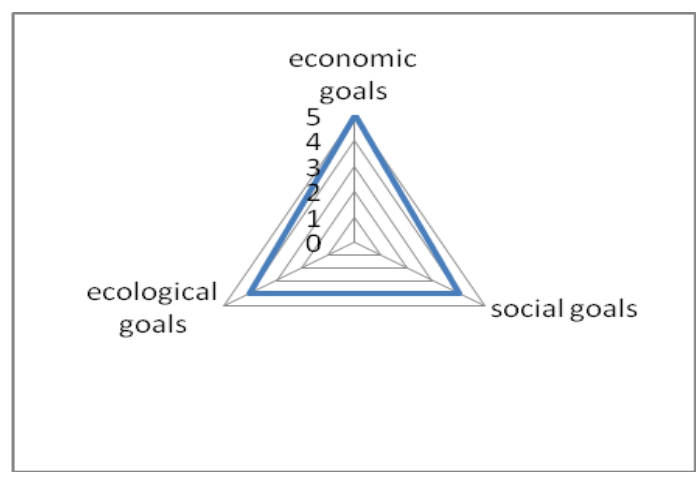

Figure 2. The role of controlling a) Defining goals

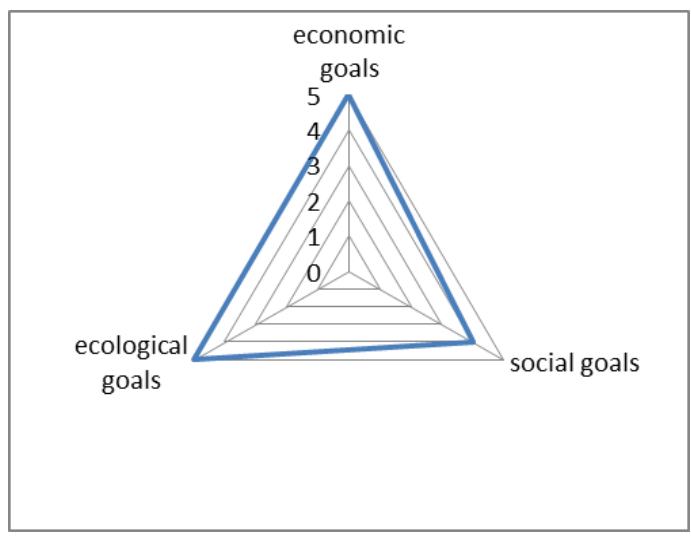

b) Planning

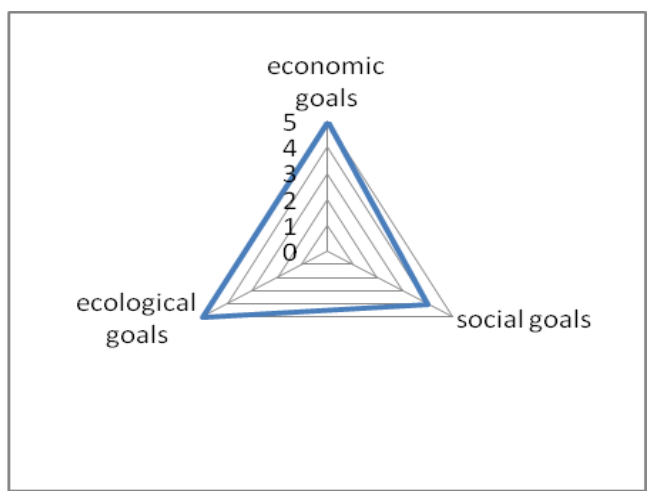

c) Reporting

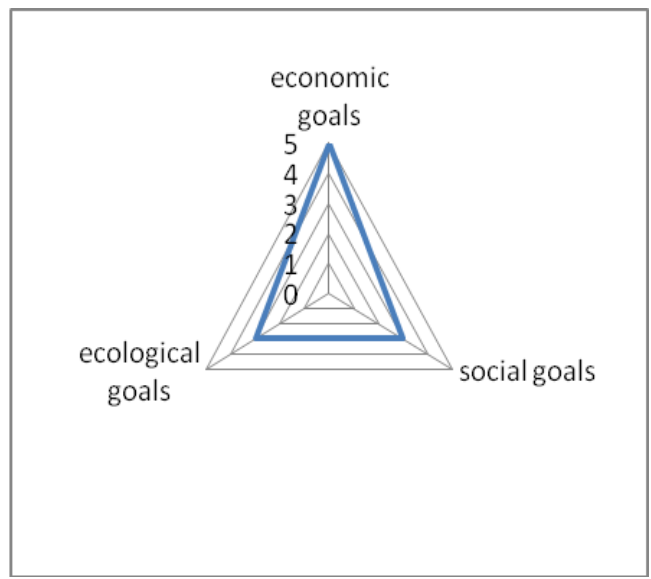

d) Control

According to research results, controlling is present and important in each partial subsystem of management. The 
most developed is in the economic field, which is certainly understandable since the controlling for decades is seen as an economic conscience of the company. Modern business is characterized by the expansion of the perspective on the social and ecological component, that is certainly a challenge for controlling and it is also the area of its future improvement.

\subsection{The role of IT in non-financial reporting}

The role of IT in sustainable reporting can be recognized in three different ways: in collection of needed data, in analysing them eg. preparing reports and distributing the reports.

Analysing the research results related with acquiring and tracking the data and indicators, we can conclude several things. Data is traced and prepared to a lesser extent manually. But in spite of that required data is monitored continuously and according to a predetermined structure and dynamics, continuous effort is still required to track the needed data from responsible company departments. It means that tracking this data and indicators are still not part of regular tasks, but requires special request. Sustainable business reporting data also includes other information from the environment and they are handled and processed manually.

In preparing their business sustainability report, Ilirija d.d. is allways using Microsoft and Spreadsheets (eg. Excel) as the software solutions. This proves that spreadsheets are still the tool that is widely used in reporting and tracking the indicators and indicators of the company's sustainable development, as we have emphasized previously, but it is obvious that Ilirija uses standard software solutions. Some more advanced business intelligence tools and reporting software solutions are not mentioned. The research also shows that Ilirija users are satisfied with the level of reporting on sustainable development and the availability of these data. Consequently, feedback from the reporting user is also positive.

The group of responses regarding the question: "How IT sector could improve the quality of information for reporting on your company sustainable business?" suggests that better ICT support is expected in all reporting segments. First, this concerns the elimination of still present manual procedures, which can be reduced. In addition, it is obvious that both, internal and external data integration can be significantly improved to track the required indicators, as well as indicators and report preparation. From the research is also evident that continuous investments are necessary for new equipment and software solutions for calculating and tracking sustainable business indicators.

The level of co-operation between llirija d.d. and other institutions (eg. Environmental Protection Agency, Ministry of Environmental Protection and Energy) on monitoring sustainable business indicators is continous. Government institutions and other organizations trace important environmental data, and corporate sustainable reporting is not just question of preparing one report on a year base, but it is very important communication channel. It serves as communication channel towards investors and capital markets, and towards guests as well. Thus it is considered as a constant flow of environmental information that should be measured and presented not only by the company but by the government and other institutions as well, and serves not only as a simple statistic fact but as objective proof of company sustainability.

\section{RESEARCH LIMITATIONS}

Non-financial reporting is expanding very intensively but still has a relatively short history. The fundamental limitation of the present study is the size of the sample. The experience of publishing non-financial reports in hotel companies in Croatia is modest [31], although there are some hotel companies that have started to publish such reports in the period 2006-2010 [31]. The adopted EU directive will certainly affect the growth of published reports in the near future.

There is already mentioned limitation of research, and relates to reduced comparability of published reports since companies have and use the freedom of choice for reporting standards / reporting principles and each report is specific and different. The problem of comparability of non-financial reports derives from the nature of the research object and is also a limitation of this research.

\section{CONCLUSION}

Sustainable business is increasingly becoming an important theme and a challenge, and it has an important impact on the company's business strategy. The modern business faces ever clearer demands for non-financial reporting, which includes reporting on social and ecological aspects of business. For many years this form of reporting has been voluntary, but we are increasingly witnessing the process of introducing the obligation of non-financial reporting and at the same time building the standards of such a report.

Traditionally, financially focused management and reporting no longer helps investors and other stakeholders understand financial and non-financial aspects of the company. Disclosure of non-financial information is crucial to linking long-term profitabillity with social justice and environmental protection. Nonfinancial reporting encompasses environmental and social aspects, the area of employee and human rights, anti-corruption measures, and then describes its own business model, outcomes and policy risks on the issues mentioned, as well as the variety of policies implemented by management and supervisory bodies.

This research is focused on discovering the best business practices and revealing the role of controlling and IT support in the process of preparing and publishing non-financial reports in hotel companies in Croatia. The research shows that there is experience and practice in sustainable reporting in hotel companies in Croatia; the Ilirija d.d. was recognized as an example of the best practice of reporting on sustainable business.

The role of controlling in this company is most significant in the economic field, and it is of great importance both in the ecological and social spheres. IT has a significant 
role in preparing and tracking data for non-financial reporting.

Research results and example of best business practice are evidence of existing experiences and open paths and areas of improvement. With this work we intended to contribute to the affirmation of sustainable business and non-financial reporting and to encourage the business community to emerge from a narrow perspective of profits and to see the broader social and environmental responsibility of the company's business. We also believe that the academic community is committed to providing support and assistance to the business community and businesses in the process of introducing and implementing reporting on sustainable business, which was the ultimate purpose of this work.

\section{REFERENCES}

[1] Amman, K., Petzold, J. 2014. „Management und Controlling, Instrumente - Organisation - Ziele“. Springer, Gabler, Wiesbaden.

[2] Baron, R. 2014. "The evolution of Corporate Reporting for Integrated Performance". Background paper for the 30th Round Table on Sustainable Development 25 June 2014, OECD Headquarters, Paris.

[3] Baier, P. 2008. „Praxishandbuch Controlling“. Moderne industrie, München.

[4] Buchholz, L. 2013. „Strategisches Controlling“. Springer, Gabler, Wiesbaden.

[5] Colsman, B. 2013. „Nachhaltigkeitscontrolling, Strategien, Ziele, Umsetzung“; Springer, Gabler, Wiesbaden,

[6] Erichsen, J. 2011. "Controlling-Instrumente von A-Z". Haufe, Freiburg.

[7] Eschenbach, R., Siller, H. 2009. „Controlling professionell, Konzepte und Werkzeuge".Schäffer-Poeschel, Stuttgart.

[8] Eropean Union. 2014. "Directive 2014/95/EU of the European Parliament and of the Council pf 22 October 2014", Official Journal of the European Union; 15 November 2014.

[9] EY. 2012. Six groving trends in corporte sustainability; http://www.ey.com/US/en/Services/Specialty-Services/ClimateChange-and-Sustainability-Services/Six-growing-trends-incorporate-sustainability Trend-4

[10] Financial Times Lexicon. 2017. http://lexicon.ft.com; December $01,2017$.

[11] Friedman, M. 1970. "The Social Responsibility of Business is to Increase its Profits". The New York Times Magazine.

[12] Gartner. "IT Glossary"; https://www.gartner.com/itglossary/internet-of-things/; 12.2017.

[13] Gartner. 2016. "Magic Quadrant for Business Intelligence and Analytics

Platforms";https://www.gartner.com/doc/3200317/magicquadrant-business-intelligence-analytics; 04 February 2016.

[14] GRI. 2017. "Benefits of reporting"; https://www.globalreporting.org/information/sustainabilityreporting/Pages/reporting-benefits.aspx\#sthash.9h6fx0hd.dpuf.

[15] GRI. 2013. "G4 Sustainability Reporting Guidelines, Reporting principles and Standard Disclosure". Amsterdam Netherland;https://www.globalreporting.org/INFORMATION/G4/ Pages/default.aspx.

[16] Horvath, P. 1991. "Controlling”. Vahlen, München.

[17] Jung, H. 2011. „Controlling“. Oldenbourg, München.

[18] KPMG. 2017. "The Road Achead, The KPMG Survey of Corporate Responsibility Reporting"; https://home.kpmg.com/xx/en/home/campaigns/2017/10/surveyof-corporate-responsibility-reporting-2017.html (12.2017.).

[19] KPMG. 2014. "The KPGM Survey on Business Reporting"; https://home.kpmg.com/xx/en/home/insights/2014/06/kpmgsurvey-business-reporting.html; 6 June 2014.

[20] KPMG. 2011. "Corporate resonsibility" https://www.kpmg.com/PT/pt/lssuesAndlnsights/Documents/corp orate-responsibility2011.pdf.

[21] Kramer, M., Kania, J., McBreen, M. 2006. "Game Changing CSR Corporate Social Responsibility Initiative”. Working Paper No. 18.
Cambridge, MA: John F. Kennedy School of Government, Harvard University.

[22] Küpper, H. U. et al. 1990. „Zum Verständnis und Selbstverständnis des Controlling“. ZfB, Gabler, Wiesbaden, 3.

[23] Law 360. 2015. „Emerging Trends in Corporate Sustainability Reporting". Expert Analysis; New York; https://www.law360.com/articles/624183/emerging-trends-incorporate- sustainability-reporting; February2015.

[24] Lider media d.o.o. 2016. „1000 najvećih hrvatskih tvrtki prema ukupnom prihodu u 2015. godini“., May 2016. Zagreb.

[25] Mayer, E. 1992. „Der werkzeugkasten des Controllers vernetzung von strategischem und operative Controlling“, in: Risak, Deyhle (Ed), Controlling State of the Art und Entwicklungstendenzen,.Gabler, Wiesbaden, p. 29-46.

[26] Osmanagić Bedenik, N., Prebežac, D., Strugar, I., Kojić, V. 2017. „Nefinancijsko izvještavanje u hotelskim poduzećima u Hrvatskoj“. Veble, Zagreb.

[27] Osmanagić Bedenik, N. 2007. "Kontroling - Abeceda poslovnog uspjeha (Controlling - Alphabet of Controlling Success)". Školska knjiga, Zagreb.

[28] Osmanagić Bedenik, N. 2015, The Challenge od Controlling, IJIEM, Vol.6 No.4, pp. 153-163.

[29] Osmanagić Bedenik, N., et al,. 2010. „Kontroling između profita održivog razvoja“; M.E.P. Zagreb.

[30] Osmanagić Bedenik, N., Lizzul, A. 2015. "Obilježja kontrolinga u dioničkim društvima na Zagrebačkoj burzi”. Zbornik Ekonomskog fakulteta u Zagrebu. 13(1): 115-128.

[31] Osmanagić Bedenik, N., Strugar, I., Labaš, D., Kojić, V. 2016. "Nefinancijsko izvještavanje - Izazov održivog poslovanja“, M.E.P., Zagreb.

[32] Peemöller, V. H. 1990. „Controlling“. Neue Wirtschaftsbriefe, herne. Berlin.

[33] Preissler, P. 1992. „Controlling in mittelständischen Unternehmen, in Risak, J., Deyhle, A. (Ed., 1992) Controlling, Gabler, Wiesbaden p. 263-294.

[34] Rob van der Meulen. 2017. What Edge Computing Means for Infrastructure and Operations Leaders; https://www.gartner.com/smarterwithgartner/what-edgecomputing-means-for-infrastructure-and-operations-leaders/ October 18, 2017.

[35] Siller, H. 2011. "Normatives Controlling". Facultas wuv, Wien.

[36] Šarac, M. 2013. „Application of controlling in banks“. Faculty of Economics and Business Zagreb, Master thesis.

[37] Šimunić, D. 2011. „Controlling instruments in small businesses“. Master thesis. Faculty of Economics and Business Zagreb.

[38] Škuflić, L., Mlinarić, D. 2015. „Mikroekonomske determinante profitabilnosti hrvatske hotelske industrije“. Ekonomski pregled, 66(5): 477-494.

[39] The Economist Intelligence Unit. 2008. "Dooing good Business and Sustainability Challenge"; http://graphics.eiu.com/upload/Sustainability allsponsors.pdf; Februar 2008.

[40] The Economist Intelligence Unit Limited. 2010. „Managing for sustainability";

http://graphics.eiu.com/upload/eb/Enel Managing for sustainabi lity WEB.pdf; 9 December, 2017.

[41] United Nations. 2016. "Outcome document of the high-level meeting of the General Assembly on the overall review of the implementation of the outcomes of the World Summit on the Information Society"; http://caribbean.cepal.org/content/outcomedocument-high-level-meeting-general-assembly-overall-reviewimplementation-outcomes; February 2016.

[42] Weber, J. 2009. „Erfolg der Controller“. Wiley-VCH, Weinheim.

[43] Weber, J. 2007. „Von Top-Controllern lernen: Controlling in den DAX 30-Unternehme". Wiley-VCH, Weinheim.

[44] Weber, J., Schäffer, U. 2008. „Introduction to Controlling“ Schäffer-Poeschel, Stuttgart.

[45] Godišnji izvještaj o društveno odgovornom poslovanju za 2017. https://ilirijabiograd.com/clients/1/uploads/liriia d d Godi\%C5\% A1nii\%20izvie\%C5\%A1taj\%200\%20dru\%C5\%A1tveno\%20odgv ornom\%20poslovanju\%20za\%202017.pdf 


\title{
Izazovi kontrolinga i IT podrške u nefinansijskom izveštavanju
}

\author{
Nidžara Osmanagić Bedenik, Darko Prebežac, Ivan Strugar, Petra Barišić
}

Primljen (03.12.2018.); Recenziran (08.01.2019.); Prihvaćen (13.02.2019.)

\begin{abstract}
Apstrakt
Danas postaje sve jasnije da finansijsko izveštavanje više ne može biti dovoljno kada se radi o poslovnom izveštavanju. U tom smislu, nefinansijsko izveštavanje je „obavezno“ u modernoj ekonomiji za različite grupe javnosti, jer odražava odgovornost kompanije da vodi poslovne aktivnosti na održiv način. Nefinansijsko izveštavanje predstavlja relativno novo područje istraživanja, a vrlo malo istraživanja je istraživalo ulogu kontrolinga i IT podrške u nefinansijskom izveštavanju. Stoga je cilj ove studije bio da se pronađu najbolje poslovne prakse $i$ da se otkrije uloga kontrolinga i IT podrške u procesu pripreme $i$ objavljivanja nefinansijskih izveštaja u hotelskim firmama u Hrvatskoj. Primenili smo pristup studije slučaja na hotelsko poduzeće llirija d.d. Rezultati pokazuju da je uloga kontrolinga u lliriji d.d. najznačajniji u oblasti ekonomije i od velikog je značaja kako u ekološkoj tako i društvenoj sferi; dok IT ima značajnu ulogu u pripremi i praćenju podataka za nefinansijsko izveštavanje.
\end{abstract}

Ključne reči: Kontroling, hotelska industrija, IT podrška, nefinansijsko izveštavanje 